\title{
Assessment and Treatment of the Supplied Pipeline Water of Selected Areas of Dhaka City
}

\author{
Zakia Aktar ${ }^{\mathrm{a}}$, ANM Fakhruddin ${ }^{\mathrm{a}}$, M. Shakir Uddin Ahmed ${ }^{\mathrm{b}}$, Tania Nasreen ${ }^{\mathrm{b}}$ and Sahana Parveen $^{\mathrm{b} *}$ \\ ${ }^{a}$ Department of Environmental Sciences, Jahangirnagar University, Savar, Dhaka-1342, Bangladesh, ${ }^{b}$ Food \\ Microbiology Section, Institute of Food Science \& Technology (IFST), Bangladesh Council of Scientific \& \\ Industrial Research (BCSIR), Dhanmondi, Dhaka-1205, Bangladesh
}

\begin{abstract}
An investigation was carried out to assess the microbiological and physico-chemical characteristics of piped water supply of different areas of Dhaka City and the results were compared with the standard value of different organizations (i.e., WHO, DoE). The results revealed that microbiologically, 88.9\% samples failed to ensure the standard level for drinking water due to the presence of TVB (total viable bacteria), TC (total coliform), TFC (total faecal coliform), TF (total fungal), Salmonella sp. and klebsiella sp. in the supplied water. However except turbidity other physico-chemical factors of supplied water were found satisfactory. Boiling for 5 minutes was found suitable for treatment of contaminated supplied water sample. Bleaching powder, sodium hypochlorite solution and Halotab were found suitable for the treatment of contaminated supplied water samples.
\end{abstract}

Key words: Water, Assessment, Microbiological, Physico-chemical parameters, Disinfectant.

\section{Introduction}

Water is essential to sustain life, and a quality (adequate, safe and accessible) supply must be ensured to all. A minimum of two liters of safe drinking water should be available per person daily to compensate the water lost in urine, faeces or perspiration (North Atlantic Treaty Organization, 2002). The sources of water in Bangladesh are surface water, rain water and ground water. Piped water supply is available to about $60 \%$ of the Dhaka city population, but the city dwellers often find that the water is contaminated and needs boiling at home for drinking because of leaks in pipeline, imperfect water taps and misuse (Nazz, 2008). In Bangladesh, about $80 \%$ of all diseases are linked with contaminated water and $28 \%$ of children's death is attributed to waterborne diseases caused by pathogenic microorganisms (Aziz et al., 1990). The international drinking water supply and sanitation decade, declared by the United Nations, ended in 1990 with an additional 1.3 billion people having access to drinking water, but still left about 1.2 billion people without access to safe drinking water (Christmas and Rooy, 1990). Each year 25 million people die due to water borne diseases and most of them are children. About 400 children below age 5 die per hour in the developing countries from waterborne diarrheal diseases (WHO, 1996).

\footnotetext{
* Corresponding author: E-mail: sahana66@gmail.com
}

Physicochemical factors are very important in case of drinking water. Certain range of these factors enhances the bacterial growth and it also determines the sanitary quality of water. Domestic sewage may contain, in addition to oxidizable material, detergents, nutrients, metals, pathogens and a variety of other compound (Mason, 1996). Action is necessary if drinking water contain total bacterial count more than $1.0 \times 10^{3} \mathrm{cfu} / \mathrm{ml}$ and any trace of Escherichia coli (WHO, 1996). Now it is necessary to treat this water properly and reduce health hazard. Despite the importance of disinfection, approximately $20-40 \%$ of urban water systems in the developing countries do not disinfect their water supplies (WHO \& UNICEF, 2000).

The main goal of drinking water treatment is to remove or kill these organisms which will ultimately reduce the risk of illness. The general purpose of water treatment under field conditions is to make water potable by removing or inactivating the pathogenic organisms and toxins from drinking water entirely or to a level at which no harmful effects will occur to the consumer (Backer, 2002). The disinfection of water means the destruction of water borne pathogens. The purpose of disinfection is to prevent direct transmission to human and to break the chain of infection by destroying 
responsible infective agents before they reach to the water environment (Kudesia, 1990). However, the treatments or disinfection processes such as boiling of the water and or adding chemicals i.e., bleaching powder, sodium hypochlorite solution and halotab etc. are extensively used to purify drinking water.

In order to find out the relationship between the health and hygiene of the inhabitants of Dhaka city with supplied water and to develop awareness among people to have pure drinking water, the aims and objectives of this study was to investigate the physicochemical, microbial parameters of the supplied pipeline water of the selected areas of Dhaka city, and to develop a suitable treatment procedure for safe drinking water.

\section{Materials and Method}

Collection of samples: The samples were collected from Mohammadpur, Kolabagan, Mirpur, Old Dhaka, Shahbag of Dhaka and Jahangirnagar University campus of Savar. Using sterilized glass bottles, water samples were collected in triplicate from three separate supplied pipelines of each location. The temperature was maintained at $4^{\mathrm{O}} \mathrm{C}$ to $6^{\mathrm{O}} \mathrm{C}$ until the completion of physicochemical and microbial analyses. Contaminated water samples were treated by physical and chemical methods for disinfection.

Physicochemical analysis: Turbidity of the samples was determined by turbidity meter while $\mathrm{pH}$ values were monitored using a digital $\mathrm{pH}$ meter and electrical Conductivity (EC) was measured by EC meter. Total Dissolved Solid (TDS) values of the samples were recorded by TDS meter, a DO meter was used to achieve the values of dissolved Oxygen (DO) of the water samples and the temperature was measured by thermometer $\left({ }^{\mathrm{O}} \mathrm{C}\right)$.

Microbial analysis: The Standard methods (APHA, 1998) were followed for the microbial analysis of the piped water samples. Lauryl Tryptose Broth (LST) and Brilliant Green Bile Broth (BGLB, 2\% w/v) were used for MPN-confirmation test of total coliform. The tubes were incubated at $37^{\circ} \mathrm{C}$ for 24 hour. A solid media Eosine Methylene Blue (EMB) agar was used for Total Colifom, E. coli and Klebsiella. The isolates were inoculated by streak plate method and incubated at $44.5^{\circ} \mathrm{C}$ for 24 hour. Total coliform and E. coli was expressed as MPN/100 ml. Plate Count Agar (PCA) and Potato Dextrose Agar (PDA) media were used to determine the total viable bacterial count and total fungi count respec- tively. PCA plates were incubated at $37^{\circ} \mathrm{C}$ for $24-48 \mathrm{~h}$ and PDA plates were incubated at $30^{\circ} \mathrm{C}$ for 3 to 5 days. E. coli and Klebsiella were confirmed by IMViC test. For confirmation of Salmonella, biochemical tests were used.

Treatment of piped water: Collected water samples were disinfected by following both the chemical and physical (boiling treatment) procedures. In case of chemical treatment procedure, calcium hypochlorite $(2 \mathrm{mg} / \mathrm{L}, 3 \mathrm{mg} / \mathrm{L}$ and 4 $\mathrm{mg} / \mathrm{L})$, sodium hypochlorite (Clotech) $(0.5 \mathrm{ml} / \mathrm{L}, 0.8 \mathrm{ml} / \mathrm{L}$ and $1.0 \mathrm{ml} / \mathrm{L}$ ) and Halotab (one Tablet $6 \mathrm{~L}, 3 \mathrm{~L}$ and $1 \frac{1}{2} \mathrm{~L}$ ) were used as disinfectants. The treated water samples were analyzed after $1 / 2$ to 1 hour contact time with disinfectants. On the other hand for physical treatment, water samples were boiled for 1, 5 and 10 minutes respectively. After cooling, the water samples were analysed for qualitative and quantitative microbial parameters.

\section{Results and Discussion}

Physico-chemical Analysis: For the survival of microorganisms, physicochemical factors play an important role. These factors such as temperature, $\mathrm{pH}, \mathrm{DO}$, TDS, turbidity, EC may be suitable for microorganisms. The dead cells of microorganisms may be act as assimilable organic carbon and the biodegradable dissolve organic carbon concentration. The residence time, presence or absence of disinfectant, pipe material characteristics, and flow conditions may be the availability of nutrients for growth of microorganisms. Hence considering the importance of physicochemical factors, the values of $\mathrm{pH}, \mathrm{DO}$, TDS, turbidity, EC etc., of water samples were first measured and the results are shown in Table I. The temperature, $\mathrm{pH}, \mathrm{DO}$ and TDS of all the tested water samples were within acceptable limit according to DoE (Khan, 2001) and WHO (1996). All bacteria which are pathogenic for human and warm-blooded animals are mesophiles, so the measured temperatures of the water samples were suitable for growth of pathogenic bacteria. For most bacteria the optimum $\mathrm{pH}$ for growth lies between 6.5 to 7.5 and the limits generally lie between 5 and 9 (Pelzer et. al, 1993). Water with high total dissolve solids may induce an unfavorable physiological reaction in the consumer (APHA, 1998). The value for EC was ranged from 231 to 1206 $\mu \mathrm{S} / \mathrm{cm}$. The standard for EC is $700 \mu \mathrm{S} / \mathrm{cm}$ and $250 \mu \mathrm{S} / \mathrm{cm}$ according to FAO (Ayres et al., 1994) and WHO respectively. Turbidity in water was due to the presence of suspended matter such as clay, silt, finely divided organic and inorganic matter, plankton and other microscopic organisms. 
Table I: Physico-chemical parameters of the supplied water samples collected from different locations of Dhaka city.

\begin{tabular}{|c|c|c|c|c|c|c|}
\hline Location & $\begin{array}{c}\text { Temperature } \\
\left({ }^{\circ} \mathrm{C}\right)\end{array}$ & $\mathrm{pH}$ & $\mathrm{DO}(\mathrm{mg} / \mathrm{L})$ & TDS (mg/L) & $\mathrm{EC}(\mu \mathrm{S} / \mathrm{cm})$ & $\begin{array}{c}\text { Turbidity } \\
\text { (FTU) }\end{array}$ \\
\hline Mohammadpur & $\begin{array}{l}22.0 \\
22.5 \\
22.0\end{array}$ & $\begin{array}{l}6.91 \\
6.80 \\
6.77\end{array}$ & $\begin{array}{l}6.41 \\
6.23 \\
6.01\end{array}$ & $\begin{array}{l}190 \\
153 \\
180\end{array}$ & $\begin{array}{l}423 \\
415 \\
410\end{array}$ & $\begin{array}{l}0.38 \\
0.38 \\
0.35\end{array}$ \\
\hline Kolabagan & $\begin{array}{l}23.0 \\
23.0 \\
23.5\end{array}$ & $\begin{array}{l}6.55 \\
6.59 \\
6.68\end{array}$ & $\begin{array}{l}5.26 \\
4.37 \\
5.02\end{array}$ & $\begin{array}{l}162 \\
450 \\
440\end{array}$ & $\begin{array}{l}1206 \\
838 \\
839\end{array}$ & $\begin{array}{c}11.94 \\
3.16 \\
1.23\end{array}$ \\
\hline Old Dhaka & $\begin{array}{l}22.0 \\
22.0 \\
22.0 \\
\end{array}$ & $\begin{array}{l}6.74 \\
6.75 \\
6.65 \\
\end{array}$ & $\begin{array}{l}5.46 \\
5.31 \\
5.39 \\
\end{array}$ & $\begin{array}{l}230 \\
268 \\
250 \\
\end{array}$ & $\begin{array}{l}483 \\
501 \\
490 \\
\end{array}$ & $\begin{array}{l}0.22 \\
0.25 \\
0.23\end{array}$ \\
\hline Shahbag & $\begin{array}{l}24.0 \\
24.0 \\
24.5\end{array}$ & $\begin{array}{l}6.88 \\
7.00 \\
6.91\end{array}$ & $\begin{array}{l}6.24 \\
5.23 \\
5.36\end{array}$ & $\begin{array}{l}232 \\
220 \\
210\end{array}$ & $\begin{array}{l}438 \\
430 \\
426\end{array}$ & $\begin{array}{l}5.29 \\
6.44 \\
5.13\end{array}$ \\
\hline $\begin{array}{l}\text { Jahangirnagar } \\
\text { University } \\
(\mathrm{JU})\end{array}$ & $\begin{array}{l}27.0 \\
27.5 \\
27.0\end{array}$ & $\begin{array}{l}6.82 \\
6.48 \\
6.71\end{array}$ & $\begin{array}{l}6.46 \\
6.01 \\
6.12\end{array}$ & $\begin{array}{l}155 \\
131 \\
190\end{array}$ & $\begin{array}{l}289 \\
231 \\
295\end{array}$ & $\begin{array}{l}0.88 \\
0.64 \\
0.75\end{array}$ \\
\hline
\end{tabular}

FTU = Formazin Turbidity Units, DO = Dissolved Oxygen, TDS = Total Dissolved Solid, EC = Electrical Conductivity, $\mathrm{mg} / \mathrm{L}=$ milligram per liter, $\mu \mathrm{S} / \mathrm{cm}=$ micro siemens per centimeter.

Turbidity of 4 tested water samples (Table I) was unacceptable for drinking according to WHO (less than 5 FTU).

Microbial analysis: Total Viable Bacterial Count (TVBC) and Total Fungal Count (TFC) of water samples are shown in Table II. Total Viable Bacterial Count in water samples were ranged from $1.2 \times 10^{1}$ to $2.0 \times 10^{3} \mathrm{cfu} / \mathrm{mL}$ (1.08 to 3.30 $\left.\log _{10} \mathrm{cfu} / \mathrm{mL}\right)$. TVBC is not a direct indicator of faecal contamination; it does indicate variation in water quality and potential for pathogen survival and growth. It was recommended that the TVBC should not exceed 500 per $\mathrm{mL}$ in tap water (LeChevalliar et al. 1980). According to WHO (1996), the standard for TVBC is $1 \times 10^{2} \mathrm{cfu} / \mathrm{mL}$. In drinking water, the TVBC may vary from less than 1 to more than 104 $\mathrm{cfu} / \mathrm{mL}$ (Maier, 2000). It was also concluded that HPC (Heterotrophic Plate Count) or TVBC in drinking water are not a health concern to the general public (WHO, 2002).

Table II: The Mean of microbial count of the supplied water samples collected from different locations of Dhaka city

\begin{tabular}{|c|c|c|c|c|c|c|c|c|}
\hline & \multicolumn{2}{|c|}{ Mean of TVBC } & \multicolumn{2}{|c|}{ Mean of TCC } & \multicolumn{2}{|c|}{ Mean of TFCC } & \multicolumn{2}{|c|}{ Mean of TFC } \\
\hline Location & $\mathrm{cfu} / \mathrm{mL}$ & $\begin{array}{c}\log 10 \\
/ 100 \mathrm{~mL}\end{array}$ & $\begin{array}{c}\mathrm{MPN} \\
/ 100 \mathrm{~mL}\end{array}$ & $\begin{array}{c}\log 10 \\
\text { IMPN } \\
/ 100 \mathrm{~mL}\end{array}$ & $\begin{array}{c}\mathrm{MPN} \\
/ 100 \mathrm{~mL}\end{array}$ & $\begin{array}{c}\log 10 \\
\mathrm{MPN} \\
/ 100 \mathrm{~mL}\end{array}$ & $\begin{array}{l}\mathrm{cfu} / \mathrm{mL} \\
\mathrm{cfu} / \mathrm{mL}\end{array}$ & $\log 10$ \\
\hline Mohammadpur & $2.3 \times 10^{2}$ & 2.36 & $9.6 \times 10^{1}$ & 1.98 & $8.1 \times 10^{2}$ & 2.91 & $2.2 \times 10^{1}$ & 1.34 \\
\hline Kolabagan & $1.2 \times 10^{1}$ & 1.08 & $1.5 \times 10^{2}$ & 2.17 & 1.0 & 0 & 6.7 & 0.82 \\
\hline Old Dhaka & $1.2 \times 10^{3}$ & 3.08 & $6.3 \times 10^{1}$ & 1.79 & $2.1 \times 10^{1}$ & 1.32 & 9.7 & 0.98 \\
\hline Mirpur & $2.0 \times 10^{3}$ & 3.30 & $1.9 \times 10^{2}$ & 2.28 & $1.5 \times 10^{1}$ & 1.18 & $1.8 \times 10^{1}$ & 1.26 \\
\hline Shahbag & $6.8 \times 10^{1}$ & 1.83 & $5.9 \times 10^{1}$ & 1.77 & 4.33 & 0.63 & 4.3 & 0.63 \\
\hline $\begin{array}{l}\text { Jahangirnagar } \\
\text { University }\end{array}$ & $3.8 \times 10^{2}$ & 2.58 & $3.7 \times 10^{2}$ & 2.57 & 4.67 & 0.67 & $2.9 \times 10^{1}$ & 1.46 \\
\hline
\end{tabular}

TVBC = total viable bacterial count, $\mathrm{TCC}=$ total coliform count, TFCC $=$ total faecal coliform count, $\mathrm{TFC}=$ total fungal count 
Total Fungal Count in water samples was ranged from 4.3 to $2.9 \times 10^{1} \mathrm{cfu} / \mathrm{mL}(0.63$ to $1.46 \log 10 \mathrm{cfu} / \mathrm{ml})$. Presence of fungus in drinking water led the deterioration of tastes and odors in water. A dramatic increase in the numbers of invasive diseases due to filamentous fungus were reported (Arvanitidou et al., 1999; Anaissie et al., 2003). The microorganisms can enter into piped water by the following ways such as broken sewer lines, congested centers, inappropriate treatment etc.

Total Coliform Count (TCC) and Total Faecal Coliform Count (TFCC) of water samples are also shown in Table II. Total Coliforml Count in water samples was ranged from $5.9 \times 10^{1}$ to $3.7 \times 10^{3} \mathrm{MPN} / 100 \mathrm{~mL}(1.77$ to $2.57 \log 10$ MPN/100mL). A high proportion of coliform in a distribution system were attributed not to treatment failure at the plant but it indicated the bacterial re-growth in the mains (APHA, 1998).

Total Faecal Coliform Count in water samples were ranged from 1.0 to $2.1 \times 10^{1} \mathrm{MPN} / 100 \mathrm{~mL}$ (0 to $1.32 \log _{10}$ MPN/100mL). These values for TCC and TFCC are unacceptable for drinking water (WHO, 1996). E. coli are usually harmless in their normal habitat (the intestine of warm blooded animals) but they can also cause diseases when they gain access to other sites or tissues of body. These diseases include urinary tract infections, septic infections, bacterimia, meningitis, pulmonary infections, abscesses, and skin and wound infections (Pelzer, 1993).

The pathogenic organisms such as Salmonella and Klebsiella were found $16.6 \%$ and $83.3 \%$ in total tested water samples respectively. The presence of faecal indicator bacteria is useful to determine the possible presence of Salmonella sp. Escherichia coli/ thermotolerant coliforms were used to indicate the possible presence of Salmonella sp. These are widely distributed in the environment and gain entry into water systems though faecal contamination from livestock, native animals, drainage waters and incompletely treated waste discharges. Faecal contamination of water which is inadequately treated or inadequately disinfected is the main cause of waterborne outbreaks of salmonellosis (Australian Drinking Water Guidelines, 2004). Salmonellas may also cause three kinds of infections: enteric fever (typhoid fever or paratyphoid fever), gastroenteritis and septicemia (Pelzer, 1993).

Klebsiella is more likely to persist in the environment and, under favourable conditions, can multiply in water. For example, in water distribution systems, Klebsiella was able to survive and even grow in drinking water as biofilms on the interior surface of water supply main lines and in storage tanks (LeChevallier et al., 1987; LeChevallier and McFeters, 1990; Edberg et al., 1994). The majority of thermotolerant coliforms isolated from a distribution system were found to be Klebsiella (Edberg et al., 2000).

Disinfection of piped water: The highest total coliform count (TCC) was $>2400 \mathrm{MPN} / 100 \mathrm{~mL}$, total faecal coliform count (TFCC) was $>2400 \mathrm{MPN} / 100 \mathrm{~mL}$, total viable bacterial count (TVBC) was $267 \mathrm{cfu} / \mathrm{mL}$ and total fungal count (TFC) was around $10 \mathrm{cfu} / \mathrm{mL}$ in untreated water from Mohammadpur area, therefore water samples of that area was selected for treatment study and the results of the boiling treatment and chemical treatments are presented in Table III and Figure 1 respectively. Table III reveals that after 1 minute boiling, the value of TCC, TFCC, TVBC and TFC were $210 \mathrm{MPN} / 100 \mathrm{~mL}, 210 \mathrm{MPN} / 100 \mathrm{~mL}, 122 \mathrm{cfu} / \mathrm{mL}$ and $0 \mathrm{cfu} / \mathrm{mL}$ respectively. Boiling of water is used for the destruction of non-spore forming pathogens sanitizes bedding, clothing and dishes. It is true that all vegetative cells will be destroyed within minute by exposure to boiling water (Pelzer, 1993). After 5 and $10 \mathrm{~min}$. boiling, no microbe was present.

Table III: Physical treatment of supplied water samples collected from Mohammadpur area of Dhaka city.

\begin{tabular}{|c|c|c|c|c|c|c|c|}
\hline $\begin{array}{l}\text { Treatment } \\
\text { of water }\end{array}$ & Time & $\begin{array}{l}\text { TVBC } \\
\mathrm{cfu} / \mathrm{mL}\end{array}$ & $\begin{array}{c}\text { TCC } \\
\text { MPN } \\
/ 100 \mathrm{~mL}\end{array}$ & $\begin{array}{c}\text { TFCC } \\
\text { MPN } \\
/ 100 \mathrm{~mL}\end{array}$ & $\begin{array}{c}\text { TFC } \\
\text { cfu/mL }\end{array}$ & $\begin{array}{c}\text { Presence of } \\
\text { Salmonella } \\
\text { sp./25 mL }\end{array}$ & $\begin{array}{c}\text { Presence of } \\
\text { Klebsiella } \\
\text { sp. }\end{array}$ \\
\hline $\begin{array}{l}\text { Before } \\
\text { treatment }\end{array}$ & & 267 & $>2400$ & $>2400$ & 10 & Present & Present \\
\hline After & $1 \mathrm{~min}$. & 122 & 210 & 210 & 0 & Absent & Absent \\
\hline \multirow[t]{2}{*}{ Boiling } & 5 min. & 0 & 0 & 0 & 0 & Absent & Absent \\
\hline & 10 min. & 0 & 0 & 0 & 0 & Absent & Absent \\
\hline
\end{tabular}

TVBC $=$ total viable bacterial count, TCC $=$ total coliform count, TFCC $=$ total faecal coliform count, TFC $=$ total fungal count 
Figure 1 presents the disinfection of microbes of piped water of Mohammadpur area by bleaching powder $(2 \mathrm{mg} / \mathrm{L}, 3 \mathrm{mg} / \mathrm{L}$ and $4 \mathrm{mg} / \mathrm{L})$, Sodium hypochlorite solution $(0.5 \mathrm{ml} / \mathrm{L}, 0.8$ due to the presence of Total Viable Bacteria, Total Coliform, Total Faecal Coliform and other pathogenic bacteria. Except the value of turbidity, other physico-chemical parameters of the supplied water from different locations were acceptable.

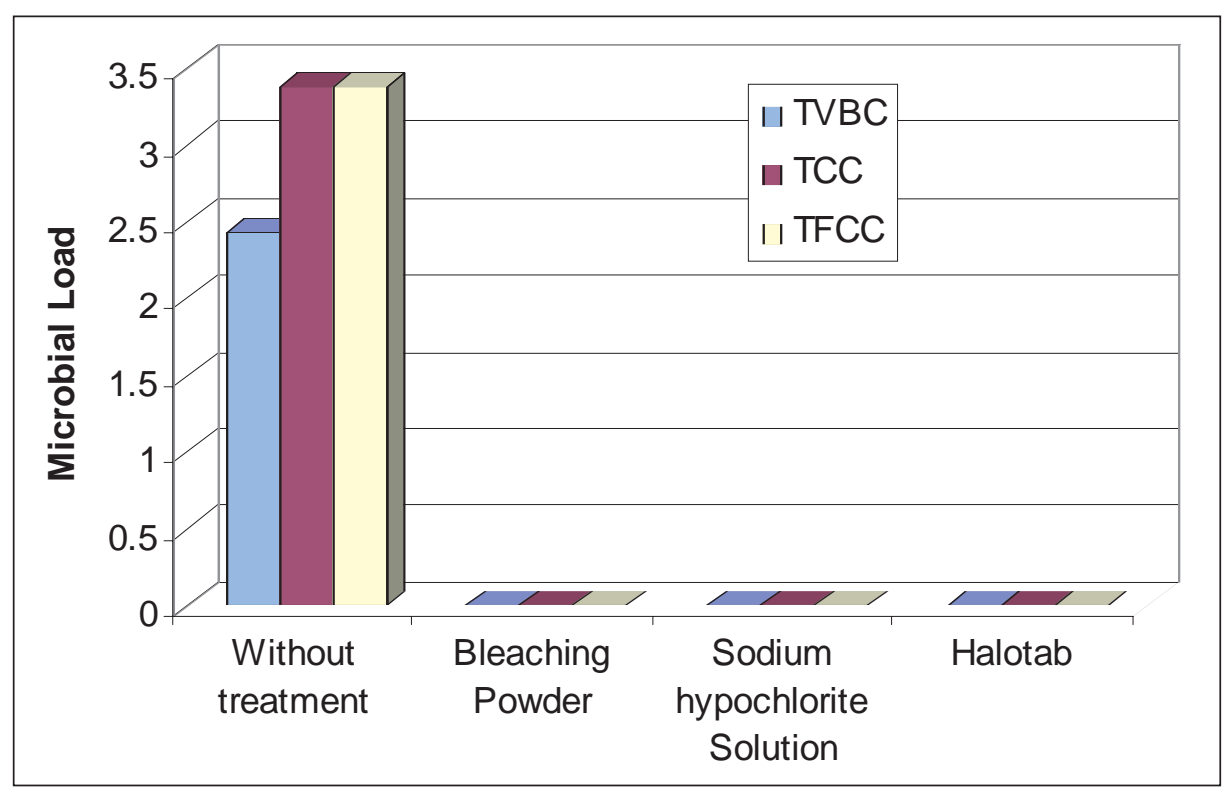

Fig. 1. Disinfection of microbes in piped water from Mohammadpur area of Dhaka city using bleaching powder, Sodium hypochlorite solution, and Halotab. TVBC = total viable bacterial count, TCC $=$ total coliform count, TFCC = total faecal coliform count.

$\mathrm{ml} / \mathrm{L}$ and $1.0 \mathrm{ml} / \mathrm{L}$ ) and Halotab (1 tablet in 6L, 1 tablet in 3L and 1 tablet in $\left.1 \frac{1}{2} \mathrm{~L}\right)$. The doses of disinfectant were added in piped water and after microbial analysis, it was found that bleaching powder, sodium hypochlorite solution and Halotab completely removed microbes from water samples of Mohammadpur area and treated water fulfilled the criteria of drinking water standard. Islam et al (2007) collected water samples from 20 different drinking water sources in Kamalapur, Dhaka city from August 2004 to January 2005. The efficacy of four disinfectants including Halotab, Zeoline ${ }^{\circledR}-200$, alum potash and bleaching powder were tested as point of use water treatment agents and noticed that alum potash, bleaching powder, Halotab and Zeoline ${ }^{\circledR}-200$ were all effective general disinfectants, Halotab and Zeoline ${ }^{\circledR}-200$ were superior to bleaching powder and alum potash against faecal coliform.

\section{Conclusion}

Eighty nine percent of the tested supplied water samples of Dhaka city were found unsuitable for human consumption
Boiling as well as use of bleaching powder, sodium hypochlorite solution and halotab were found suitable for the treatment of contaminated supplied water. According to Islam et al (2007), Zeoline®-200 was used at four drops per litre for 5 minute, Halotab was used as per the instruction of the manufacturer, i.e. one tablet per $3 \mathrm{~L}$ of water for 30 minute, Bleaching powder was used at $1.25 \mathrm{~g}$ per 20L for 30 min. in heavily contaminated samples and also found effective for water treatment.

\section{References}

Anaissie E. J., Stratton S. L., Dignani M. C., Lee C., Summerbell R. C., Rex J. H., Monson T. P. and Walsh T. J. (2003) Pathogenic molds (including Aspergillus species) in hospital water distribution systems: a 3-year prospective study and clinical implications for patients with hematologic malignancies. Blood 101: 2542-2546.

APHA (1998) Standard methods for the examination of water and wastewater. 20th edition. American Public 
Health Association/American Water Works Association/Water Environment Federation, Washington, DC, pp 853.

Arvanitidou M., Kanellou K., Constantinides T. C. and Katsouyannopoulos V. (1999) The occurrence of fungi in hospital and community potable waters. Lett. Appl. Microbiol. 29: 81-84.

Australian Drinking Water Guidelines (2004) Australian Government, National Health and Medical Research Council. Vol 6, pp 263.

Ayres R. S. and Westcot, D.W. (1994) Water Quality for Agriculture. FAO Irrigation and Drainage Paper 29 Rev 1.Rome, Italy:FAO.

Aziz K. M. A., Hoque B. A., Huttly Minnatullah S. K. M., Hasan Z., Patwary M. K., Rahaman M. M. and Cairncross S. (1990) Water supply, sanitation and hygiene education. Report of health impact study in Mirzapur, Bangladesh. Water and Sanitation series No. 1. The World Bank, Washington DC.

Backer H. (2002) Water disinfection for international and wilderness travelers. Clin. Infect. Dis. 34:355-364.

Christmas J. and de Rooy C. (1990) The decade and beyond: at a glance. New York: UNICEF Water Sanit. Sect., Program Div.

Edberg S. C., Rice E. W. Karlin R. J. and Allen M. J. (2000) Escherichia coli: the best biological drinking water indicator for public health protection. Symp. Ser. Soc. Appl. Microbiol. 29:106S-116S.

Islam M. A., Brooks A., Kabir M. S., Jahid I. K., Islam M. S., Goswami D., Nair C., Larson G. B. and Yukiko W. Luby S. (2007) Faecal contamination of drinking water sources of Dhaka city during the 2004 flood in Bangladesh and use of disinfectants for water treatment. Journal of Applied Microbiology. 103 (1): 8087.

Khan A. A. (2001) Environmental Law. New warsi Book Corporation. Dhaka, pp 318-319.

Kudesia V. P. (1990) Water pollution (Principles of disinfection of drinking water and its analysis). Pragati prakashan. India, pp 109.
LeChevallier M. W,. Seidler R. J. and Evans T. M. (1980) Enumeration and Characterization of standard plate count bacteria from drinking water. Appl. Environ. Microbiol. 45: 484-492.

LeChevallier M. W., Schiemann D. A. and McFeters, G.A. (1987) Factors contributing to the reduced invasiveness of chlorine-injured Yersinia enterocolitica. Appl. Environ. Microbiol., 53: 1358-1364.

LeChevallier M. W., Lowry C. D. and Lee R. G. (1990) Disinfection of biofilms in a model distribution system. J. Amer. Watr Works Assoc., 82(7): 87-99.

Mason C. F. (1996) Biology of fresh water pollution. Third ed. Longman Group Ltd England, pp 18.

Maier R. M., Pepper L. L. and Gerba, P. G. (2000) Environmental Microbiology. Academic Press. California. USA, pp. 491-493.

Nazz S. (2008) National Encyclopedia of Bangladesh, Asiatic Society of Bangladesh.

North Atlantic Treaty Organization. (2002) Minimum Standards of Water Potability during Field Operations and in Emergency Situations. STANAG 2136 (Edition 4). NATO Standardization Agency, Brussels, Belgium, pp 325.

Pelzer J., Chan E. C. S. and Krieg N. R. (1993) Microbiology. International edition. McGraw Hill. Inc. London, pp 112-113,798.

WHO. (1996) Guidelines for Drinking-water Quality, 2nd edn.. World Health Organization (WHO), Geneva, Switzerlan, 2:. 132-167.

WHO \& UNICEF. (2000) Global Water Supply and Sanitation Assessment 2000 Report. Iseman Creative, Washington.

WHO. (2002) Heterotrophic plate count measurement in drinking water safety management. Report of an Expert Meeting, Geneva, 24-25 April 2002. Department of Protection of the Human Environment, Water, Sanitation and Health, World Health Organization, Geneva.

Received : October 20, 2008;

Accepted : April 27, 2009 